\title{
Reflections:
}

\section{Social assistance: theoretical underpinnings}

\section{Minas Hiruy ${ }^{1}$}

Key words: marginalized community, social assistance, social welfare, MDGs, development.

The case of the marginalized and how society regarded or responded to the same has played a significant part in shaping human history, philosophy and religious development. From the looks of it, the issue has not been laid to rest as society debates the share of the marginalized in the resources that are gained in a given society. Whether one calls it class struggle or competition for the ever dwindling resources, claims and counter claims have taken both amicable and violent forms between the haves and the have-nots. Much literature reflects this tug of war that has increasingly transcended national borders. A lot of movements and groupings have emerged over the years to close the gap of resource accessibility and to bring about a community where no one suffers from want and/or exclusion.

Social justice as it is called has not come easily to many societies. Many sacrifices have been made in bringing about a playing field where the poor could not be ignored for the many lacks that they may have. From this tension, many gains of goodwill that have their own pivotal roles in making for mature and great societies have been made. From early on, the poor have had many allies. The ancient giants of thought and faith have appealed to all of means to share what they have with the less fortunate and have staked character primarily on the basis of one's sense of obligation to the poor.

Whether virtue or beneficence or piety, these concepts have come to characterize much of the stance of society towards the poor. The Judeo Christian tradition went further in making care for others as the epitome of the love that it advances. Islam regards

\footnotetext{
${ }^{1} \mathrm{PhD}$, Hope University College.
} 
the show of kindness to the poor as one of the pillars of the faith. In this appeal, what is underscored is not just the willingness to give but also the right to receive. With this background, it is not surprising for some one like Aristotle to join the same band wagon and regard kindness as a defining feature of humankind and for Cicero to have a similar stance by saying, "justice commands us to have mercy on all” (Trattner, 1998).

With the teachings of giants such as the above, helping others has become the centerpiece of socio-political culture. This development has led to the involvement of the state in social services. The United Kingdom broke ground in this regard with the enactment of the Poor Laws in 1601. From that point, the social welfare movement has taken foothold in a number of countries (ibid). On a multilateral level, the poor have a number of forces that appeal on their behalf. The famous World Summit for Social Development that occurred in Copenhagen in 1995 elevated the agenda of social welfare for the poor and gained commitment on how to respond from most heads of state and government. At this summit, nations were urged to invest at least $20 \%$ of their budgets to social development. The Millennium Development Goals that were adopted by the UN in a summit of 192 heads of state and government in September 2000 were more explicit about poverty reduction endorsing the well known eight millennium goals. This UN summit also put in place monitoring mechanism to assess the performance of the signatories. A number of other universal protocols and declarations have appealed for the inclusion of the poor and meaningful responsiveness to the poor.

For a number of years now, virtually all countries in the north and a growing number of countries in the south have introduced social assistance programs to attend to the needs of their own poor. This outreach, which has increasingly taken a global profile, has not gone without philosophical underpinnings. Modern man, whether being influenced by his inner voice or by the various marches for fairness and a better day, has not certainly ignored sensitivity to the needs of the poor. 
The bone of contention in social assistance has been not so much the end but the means. A hard look in this regard finds two hidden forces that have swayed thoughts in one way or the other. These forces are need on one hand and merit or desert on the other. From these forces, theories of social response have developed in terms what I see as need-based social assistance, merit-based social assistance and need and merit-based social assistance.

\section{Need-based social assistance}

Need-based social assistance hinges assistance on need. Need of course comes in its physical and psycho-social gaps with the former pertaining to physical poverty and the latter to spiritual poverty. Physical poverty revolves around physical needs. Psycho-social need revolves around safety, security and selfimportance needs. These needs become pressures for change like necessity has become the mother of invention. The pressures of need are usually internally absorbed in the initial phase as an individual tends to bear them. But, if the pressures are unattended, they often spill over into society and bring about open stirrings for change. The psycho-social pressures, which in some sense are outcomes of physical needs, take more time to develop. But they have the same consequences as the physical pressures.

According to the school of need-based social assistance, response to needs is unconditional to the extent helping the unfortunate is regarded as a social imperative. To this outlook, while the community is the cornerstone of society around which everyone revolves, the individuals within the community are regarded as irreplaceable building blocks to hold the community together. This being so, attending to the needs of each and every one becomes a must to avoid personal disaffection and thus the collapse of the community. Hence, this school is apt to contend, "the freedom from hunger and destitution is an inalienable human right that should be legislated by national governments and delivered as a legal obligation of the state” (Ellis et al, 2009: 8).

Here as the aim is to bring all to an acceptable standard of life and in so doing to avail the fairness and justice that are regarded indispensable for a healthy society, the whole effort is called 
organicism. And to the extent resource allocation plays the main part in meeting needs, distributive justice has come as a telling designation for this exercise. In this working, what is shared is not the crumbs that people may have but the results of any social achievement. Hence, this school is said to appeal to the notion of equality of results.

To a number of countries, this stance is not just theoretical. The Nordic countries have introduced a welfare state that has not left social assistance to just the whim of individuals. From the earliest of times, the state has taken the responsibility of caring for the unfortunate while the ordinary citizen contributes dearly by way of taxes to address the multitude of needs that are not even thought of in most other countries. In as much as the need response is vast, the financial resources raised are also enormous. And as people invest in social care via taxes, their part in charitable contributions is often minimal. Their argument is as precious and as necessary as caring for a human being is, why should this responsibility be left to the whim of anyone. Many of the countries in north-west Europe and Canada have also taken on social assistance as the responsibility of the state.

This outlook has a different stance on motivation and the stirrings of development as well. The school refrains from linking development achievements to an individual considering the various contributions of the community to that achievement. To this school of thought, the effort to excel must be exercised to get not just personal rewards but the satisfaction that comes from contributing to the commonwealth.

To this school, while "nature's lottery" may endow one with special gifts and another with certain handicaps, in the eye of the community, both are equal in terms of their access to community resources and this social assurance is said to yield a collective gain that outweighs individual gain. From this greater achievement, it is contended there is not only better quality of life but also better attachment to one another without the loneliness and insecurity that often comes with the pursuit of just selfinterest. 
The school sees a society anchored on such philosophy more achieving than that leaves one to his wit and gut. This kind of egalitarianism cuts deep in much social theorizing principally due to the view that "human life begins and develops sharingly or it does not begin or develop at all” (Maguire, 1980: 76). Sharing, "as a precondition of human flourishing," is pictured by Maguire as an indebtedness of one to another. This indebtedness, if left not to mature, is said to mean, according to Maguire, social disintegration and the imperiling of the worthiness of persons (ibid) and, according to Furniss and Tilton (1977), the paralysis of genuine cooperation, friendship and even freedom.

The significance of egalitarianism is also predicated on the presumption about the justice of man. While the whole notion of man's original goodness is controversial, the imputed virtuousness of man is something that those who uphold to the equality of man have propounded with certainty. The disposition that "from conception until death human life unfolds under the physical law that to be is to share" is central to this stance (op. cit: 77). This belief in "the inborn altruism" and love of each other; has meant that altruism has had to blame inequality on "bad social conditions and institutions" (Downie, 1971: 32). With this "externalized" diagnosis, altruism has been rather relentless in its prescriptions to dismantle the very conditions purported to have imposed the burden of inequality on an otherwise just man.

In this campaign for justice, a social ethicist such as Rawls (1971) argues that a social system based on even merit is unjustifiable. Much to the chagrin of Zimmerman, who perceives such a position as a "new form of original sin," Rawls (ibid), contending that inequity is a function of underserved "inequalities of birth," actually calls for measures of redress or compensation. Similarly, Maguire (1980) expresses his stance on merit by asserting, "The presupposition of equal opportunity that those who have deserve and those who don't have are inferior is the basis of class and caste. The ideology of equal opportunity is an insidious pretension calculated only to maintain inequities” (ibid: 102).

The school of thought asks, what ground is there for one to live below acceptable human conditions and for another in opulence. 
There is also the thought that once class formations are in place, those that behold to their privileges tend to refrain from efforts of equalization contending, "While relief should not be denied of the poor, life should be so miserable for them that they would rather work than accept public aid” (Trattner, 1998: 52).

The upshot of this disposition is a scheme of justice whose unqualified responsiveness to human needs makes it, as Maguire (1980: 65) asserts, "a minimal manifestation of humaneness, the alternative to which is barbarity". This school of thought detests merit seeing it as the field and fertilizer of unhealthy competition where the victor and the gains elevate the individual rather than the community.

Social service systems along the above approach have been espoused and applied by many countries. The Great Deal of the 1930s and the Great Society of the 1960s in the United States came with a number of social legislation and began to address the rising scale of social burdens through a robust welfare system that involved both the government and benefactors. The Nordic countries developed a strong and generous social welfare under the leadership of the state. Owing to the social infrastructure in these societies, begging pretty much experienced natural death. A number of developing countries have tried to do the same with varying degrees of coverage that is directly tied not only to public will but also to financial capacity.

\section{Merit-based social assistance}

To those who condition merit for humanitarian response, more goes than what meets the eye. Here assumptions about human nature frame the basis of one's outlook. Man's infallibility and tendency to falter is assumed in any interaction. This being the case, it is thought that unless people are put in a position to earn what ever they get from society, they may conduct themselves in a manner that is dangerous to them and to society. In this regard, it is said that assisting the poor on the basis of need may make them lazy or dependent and this in turn is believed to worsen their poverty than to improve it. 
This thinking sees marginalization not as a product of political economy but of the affected himself (Trattner, 1998: 56). There is also the fear that the more assistance is given on a silver platter, the more one has to support the receiver as public aid becomes "like a drug" (ibid). Most importantly, it is stated that with free public assistance removing "the dread of want" public assistance destroys the incentive to work and causes "the poor to become even more idle and improvident” (ibid).

This thought, which arose primarily from social Darwinists and the laisez faire economics of the $19^{\text {th }}$ century, is of the stance that unless one earns his/her way to assist himself, the choice left is to depend on others and this dependence is seen as a sure way to destroy society. Holding this view, this thought decries any tampering with one's earnings to transfer resources to the poor as a violation of a natural right. In this sense social assistance is regarded as an interference contending that "money spent to support paupers comprised wages withheld in the form of taxes from industrious workers” (ibid: 50).

To the school of merit based response, stipulating merit not only enables the poor to use his/her energies to overcome poverty but also to achieve even more. Nash contends that the egalitarianism implicit in social justice that disregards merit overlooks "the role that the gifted can play in raising the level of the rest of society" (ibid). In Nash's view, as long as social justice fails to reward individual achievement, it curtails the incentives to produce on the one hand and induces the recruitment of an ever increasing number of dependents on shrinking resources on the other"(ibid, 63). The same effort of social leveling is also seen as a "war on the poor" to the degree, as Hospers (1971: 306) remarks, an "intervention throughout the economy has blocked at every turn the efforts of the poor to improve their own lot, leaving them no choice but to be victims of handouts.

This idea of a system of welfare being unable to mitigate the cycle of poverty is supported by Skinner (1978), given his position that “....we may not really help others by doing things for them.... By giving too much help we postpone the acquisition of effective behavior and perpetuate the need for help...." And 
with endless dependency increasingly blamed on social outreach, Hosper's comment that "the net effect of the humanitarian's effort is to underwrite the ethics of parasitism and to condemn or demean the ethics of work" expresses a rather common argument (op. cit, 296). Similarly, Hocutt (1982) portrays equalization as negative incentive, considering that 'it can be used to encourage some people to reduce their efforts on the baseless supposition that others are doing so".

In as much as merit based response contends that public assistance "creates an appetite which is more harmful than the pain it is intended to relieve", and encourages "laziness and other negative personal values..."...that keep "the poor mired in cycles of dependency", it regards work as the panacea to overcome poverty (Trattner, 1998: 396). When the school is challenged about what to do when work is not available, the school challenges the creativity of people in overcoming their dire circumstances.

Banking on this capacity for self-help, the literature in social welfare shows some legislation and practice that prohibit begging without availing viable social assistance. For instance, the Statue of Laborers of 1349 did just that and the Act for the Punishment of Sturdy Vagabonds and Beggars of 1536 attached severe punishments to the poor who had to beg to survive (ibid). Today even a poor country such as Afghanistan has made begging illegal (Integrated Regional Information Networks- IRIN, 2009).

However, as complex as the world has been, merit could not hold up in many situations where individuals being repressed cannot compete to achieve or to benefit from their merits. There is also the issue of justice as fairness in a situation where past disadvantages deter one from benefiting from equality of opportunity.

Given this murkiness, merit-based social assistance does not have adequate answer to those who cannot work because of sickness, young age, old age or unemployment and to those, who are left out by exclusive playing fields. The neglect of innocent and fragile people like children and the aged, have meant unbearable 
conditions. Living in such conditions of neglect and isolation, in turn has meant the making of candidates "for the prison or the grave." on one hand and developments such as thievery, rioting and social disorder on the other.

\section{Need and merit-based social assistance}

This response tries to address the weaknesses of one school of thought by the strengths of the other school of thought. In this regard, a lot can be derived from the merit-based social assistance to address the dependency and cost causing behavior associated with the need-based social assistance. Here, an environment can be set with various stipulations for those on assistance but who are physically able to work. In this conditionality, the system will also have to invest in changing the attitudes and confidence of beneficiaries about earning their living and in preparing them for the labor market by way of training.

The Poor Laws of 1601 learned this lesson and stipulated work for the able bodied (Trattner, 1998: 10). In the US, the Work Incentive Program of 1967 initiated a similar step. Then the Personal Responsibility and Work Opportunity Reconciliation Act of 1996 repealed welfare payments by requiring all those able to work to find employment within a period of two years. The same act had provisions for training for those who need to retool themselves to fit market requirements (ibid). As difficult as the application of this act was on the poor, the employment requisite seemed to have worked re-channeling or as the literature has it "moving" those on public dole to self assistance. This step in turn addressed the problem of welfare cost by saving billions of Dollars and lessening the tax burden.

Easing up on taxes as the poor began to help themselves had twin consequences. On one hand, it contributed to the expansion of the economy and the opening up of employment opportunities to those who were formerly depending on the public dole. On the other hand, it released a lot of income for companies and wage earners who turned around and gave to charities from their incomes. From this resource, a number of charitable organizations have been able to raise billions of Dollars to attend to the needs of 
others. Since the 70s, companies have also taken the idea of social responsibility in their best interest and began to have a charity arm to help the poor directly as well as to have their staff members be involved in poverty alleviation. Governments have been encouraged by this show of goodwill to the less fortunate and have come up with legislation and institutional frameworks to encourage and facilitate this social investment.

On the other hand, as to the basic deficit of merit-based social assistance, that is, what to do with those who need help but could not help themselves largely due to physical, mental and age handicaps, need-based social assistance can come to help. To many observers, the world is still too hostile for many to address their needs through their own earnings. Here to the extent the poor continue to be a reality, need-based social assistance will have to continue as well. The Poor Laws have allowed this provision as have a number of systems that reformed themselves. 


\section{References}

Downie, R.S. 1971. Roles and Values: An Introduction to Social Ethics. London: Mehuen \& Co., Ltd.

Ellis et al. 2009. Social Protection in Africa. Northampton, MA: Edward Elgar Publishing Limited.

Furniss, N., Tilton, T. 1977. The Case for the Welfare State. Indiana: Indiana University

Hocutt, M. 1982. Toward an Ethic of Mutual Accommodation. In Humanist Ethics.

Hospers, J. Libertarianism. 1971. Los Angles: Nash Publishing.

Integrated Regional Information Networks- IRIN. June, 2009.UN Office for the Coordination of Humanitarian Affairs, New York.

Maguire, C. D. 1980. A New American Justice. New York: Doubleday and Co., Inc.

Rawls, J. A Theory of Justice. Cambridge, Mass.: Harvard University Press.

Skinner, B. F. 1978. The Ethics of Helping People. In Deats, Paul (Eds). Altruism, Sympathy and Helping. New York: Academic Press.

Trattner, I. W. 1998. From Poor Law to Welfare State, $\left(6^{\text {th }}\right.$ Edition), New York: The Free Press. 